\title{
AMMONIA DETERMINATION IN BOTTLED WATER USING SPECTROPHOTOMETER : COMPARISON BETWEEN NESSLER AND BERTHELOT METHODS
}

\author{
Ashadi Sasongko $^{1^{*}}$, Rista Wahyu Nugroho ${ }^{2}$, Dini Mulyani ${ }^{3}$ \\ ${ }^{1}$ Kalimantan Institute of Technology (ITK), Karangjoang, Balikpapan, Indonesia, 76127 \\ ${ }^{2}$ Customs Laboratories BPIB, JI. Letjend Suprapto No.66, Jakarta, Indonesia, 10520 \\ ${ }^{3}$ Center for Supervision and Quality Control (BPMB), Ciracas, Jakarta, Indonesia, 13740 \\ ”e-mail: ashadisasongko@itk.ac.id
}

\begin{abstract}
Ammonium concentration in bottled drinking water should not exceed $0.15 \mathrm{ppm}$. National Standardization Agency of Indonesia (BSN) had issued two standard methods for analysis, Nessler and Berthelot. The objective of this research was to statistically compare the validity of both methods including parameters of linearity, precision (variance coefficient) and accuration (\% recovery). In Nesler method, preparation was only by adding the Nessler reagent that contains alkaline solution of potassium mercuric iodide, into the sample. Whereas in the second one, the addition of reagent that contains alkaline solution of phenol and hypochlorite should be prepared freshly. The results showed that the variance coefficient of the first method was $3.41 \%$ with linearity 0.9995 and recovery was $101.05 \%$. Whereas variance coefficient of second method was $3.64 \%$ with linearity 0.9995 and recovery was $105.62 \%$. Significance test between the methods showed that value of $F_{\text {exp }}(1.043)$ was less than $F_{\text {crit }}(4.284)$, and value of $t_{\text {exp }}(2.36)$ was less than $t_{\text {crit }}$ (2.45) in interval of confidence $95 \%$. There was no significant difference between two methods.
\end{abstract}

Keywords : Berthelot method, Nessler reagent, precision, accuracy

\begin{abstract}
Abstrak
Konsentrasi ion ammonium dalam air minum kemasan tidak bolehmelebihi 0,15 ppm. Badan Standardisasi Nasional (BSN) telah mengeluarkan dua metode standar untuk analisis, Nessler dan Berthelot. Tujuan dari penelitian ini adalah membandingkan secara statistik validitas dari kedua metode mencakup parameter linieritas, presisi dan akurasi. Pada metode Nessler, preparasi dilakukan hanya dengan menambahkan reagen Nessler yang berisi larutan basa dari kalium merkuri iodida ke dalam sampel. Sedangkan pada metode Berthelot, penambahan reagen yang mengandung larutan basa dari fenol dan hipoklorit harus selalu baru. Hasil penelitian menunjukkan koefisien variansi metode pertama adalah $3,41 \%$ dengan linieritas 0,9995 dan $\%$ recovery sebesar $101,05 \%$. Sedangkan koefisienvariansi metode kedua adalah $3,64 \%$ dengan linieritas 0,9995 dan $\%$ recovery sebesar $105,62 \%$. Uji signifikansi antara keduametode menunjukkan bahwa nilai $F_{\text {hitung }}$ $(1,043)$ kurang dari $F_{\text {tabel }}(4,284)$, dan nilai $t_{\text {hitung }}(2,36)$ kurang dari $t_{\text {tabel }}(2,45)$ pada rentang kepercayaan $95 \%$. Tidak ada perbedaan yang signifikan antara dua metode.
\end{abstract}

Kata kunci: metode Berthelot, pereaksi Nessler, presisi, akurasi

\section{INTRODUCTION}

Ammonia is listed as a toxic compound in an aquatic environment. High concentrations of ammonia in drinking water and other water resources can lead to adverse effects for human and environment. The allowable levels of ammonia concentration in fresh and drinking water is in the range from 0.5 to $3.0 \mathrm{ppm}$ depend on the local regulation of states and certain areas in the world (Loan et al., 2013).

In Indonesia, pure water parameters were regulated by Decision of Health 
Minister (Kepmenkes) 907/SK/VII/2002 about Specification and Quality Control of Drinking Water. It comprises physical, chemical, and microbiology parameters. First, physically, water should be odorless, tasteless, colorless, and should not be turbid. Secondly, in the chemical specification, drinking water may not exceed the maximum level of harmful compounds and metal contamination. One of the chemical parameters is the level of ammonia not exceed $0.15 \mathrm{ppm}$.

National Standardization Agency of Indonesia (BSN) has used two standard methods for the analysis of ammonium content in bottled water: Nessler (SNI 0103554-1998) and Berthelot method (SNI 0103554-2006). Nessler method can be used to measure ammonia with minimum levels of $0.02 \mathrm{ppm}$. Whereas the (Berthelot method) was able to detect the level of 10 $\mathrm{ppb}$, but the weakness was the reagent (a mixture of phenol and $\mathrm{NaOH}$ ) is unstable. This method was proper when reagents prepared freshly. In ammonia determination, both are more preferable than titrimetric method because more sensitive (Tzollas et al., 2010; Park et al., 2009; Loan et al., 2013)

Ammonium can be determined by some methods, i.e. spectrophotometry, fluorometry, conductometry, and potentiometry. Ammonium determination using spectrophotometry is based on reaction among ammonium, hypochlorite and phenol. Ammonium ion reacts with hypochlorite and phenolic compounds to form an indophenol blue derivative. The reaction is called Berthelot reaction. Phenol, sodium salicylate, thymol, o-phenyl phenol, and 1-naphthol can be used as sources of phenolic compound on Berthelot reaction. Sodium hypochlorite and sodium dichloroisocyanurate (DIC) have been used as starting material for chlorine. It has been also reported that the addition of nitroprusside improved the sensitivity of Berthelot reaction (Shoji and Nakamura, 2009). In Nessler method, the result becomes inaccurate if there are interfering substances such as $\mathrm{Cl}_{2}, \mathrm{Cl}^{-}$, hardnesscausing compounds (e.g. $\mathrm{Mg}^{2+}$ ), and $\mathrm{Fe}^{2+}$ in target water samples (Jeong et al., 2013). It was usually used but this method was lack of sensitivity and requires the use of toxic mercury compound. Consequently, method based on Berthelot reaction between ammonia, chlorine and phenolic compounds to form indophenol dyes, have become more popular (Tzollas et al., 2010).

In Korea, ammonia analysis by the Berthelot method could be improved and optimized in any aspect, including reagent dosage, procedure and instrument. Upon comparing Korean Standard Methods (KSM) to those of other countries, such as the United States, Germany and Japan, it was found that the dosage of phenol and $\mathrm{NaOH}$ are far more excessive in Korea. Usage of phenol is controlled by the governmental Center for Chemical Safety Management (CCSM), so it is desirable to minimize the usage of it if possible (Park et al., 2009). Hasri and Mudasir (2002) reported the effect of ethanol addition and solution heating on the analytical performance of the determination of ammonia in water by Berthelot method. Results of the study showed that ethanol addition into analytical solution and solution heating enhanced the formation of indophenol blue.

Tenzer Dieter (1992) had patent of means and method for the determination of ammonia ions, based on Berthelot method. But there was no comparation between the method with the older one, Nessler method. The methods can be compared, technically (ease of handling and safety) and statistically.

This study not only compared the proximity of the results of the analysis, but also used statistical methods to justify the differences between the two methods. Results of the analysis were statistically processed to provide a description of differences between two methods including linearity, precision, accuracy, and significance test. The results also can be used as reference for analyst or laboratory of analysis to analyze ammonia in water. Data relating accuracy, precision etc. are parts of a method follows a standardized set of experimentaltests in validation or verification. Significance test is used to 
know whether the two methods is significant different or not.

\section{METHODS}

\section{Apparatus and Reagents}

The materials used were a sample of bottled water, $\mathrm{H}_{2} \mathrm{SO}_{4}, \mathrm{Na}_{2}-\mathrm{EDTA}, \mathrm{NaOH}$, $\mathrm{Hgl}_{2}, \mathrm{KI}$, anhydrous $\mathrm{NH}_{4} \mathrm{Cl}$, demineralized water, phenol, ethanol, sodium nitroprusside, trisodium citrate, sodium hypochlorite, and the filter paper. The instruments used were UV-Visible Spectrophotometer Perkin Elmer Lambda 35 and analytical balancePrecisa XT $220 \mathrm{~A}$.

\section{Preparation of Reagents}

The volume of $30 \mathrm{~mL}$ ammonium standard solution $10 \mathrm{ppm}$ was poured into $1000 \mathrm{~mL}$ volumetric flask and added with sample of bottled water. The solution was used as a sample. Rest of water was used as a blank.

Solution of sodium nitroprusside $0.5 \%$ $\mathrm{w} / \mathrm{v}$ was prepared by dissolving $0.5 \mathrm{~g}$ of sodium nitroprusside in $50 \mathrm{ml}$ beaker, then transferred into a $100 \mathrm{~mL}$ flask and added with distilled water. Alkaline citrate solution was made by dissolving $200 \mathrm{~g}$ of trisodium citrate and $10 \mathrm{~g}$ of sodium hydroxide in a beaker of $250 \mathrm{ml}$ with distilled water and then transferred to a flask $1,000 \mathrm{~mL}$, and tared by using distilled water. Oxidizer solution was prepared by mixing $100 \mathrm{~mL}$ of alkaline citrate with $25 \mathrm{~mL}$ sodium hypochlorite solution and stirred until homogen.

\section{Procedures}

\section{Nessler Method}

The volume of $50 \mathrm{~mL}$ sample was put into a $100 \mathrm{~mL}$ Erlenmeyer flask. One drop of EDTA was used to eliminate turbidity. Sample was added with $2 \mathrm{~mL}$ Nessler reagent. The solution was let for $10-30$ minutes after the addition of Nessler reagent. Then the sample was analyzed. Absorbance was measured at $420 \mathrm{~nm}$. Spiked samples measurement was performed 7 repetitions.

\section{Berthelot Method}

The volume of $25 \mathrm{~mL}$ of sample was put into Erlenmeyer flask, then added $1 \mathrm{~mL}$ of phenol, $1 \mathrm{~mL}$ sodium nitroprusside, and $2.5 \mathrm{~mL}$ of the oxidizing solution (mixing between sodium citrate and sodium hypochlorite) then was shaken. Sample, blank and standard were covered with a plastic lid, let the colors arise in room temperature, and protected from light. The color was stable in 24 hours. Absorbance was measured at $640 \mathrm{~nm}$. Spiked samples measurement was performed 7 repetitions.

\section{Calculation of $\%$ recovery and $\%$ RSD}

Accuracy of Nessler and Berthelot methods was stated as $\%$ recovery.

where,

$$
\% \text { recovery }=\frac{a-b}{c} \times 100 \%
$$

$a=$ measurable concentration of sample + concentration of standard

$b=$ concentration of sample

$\mathrm{c}=$ theoretical concentration of standard

Whereas precision of both methods was expressed as relative standard deviation (\% RSD).

where,

$$
\% \mathrm{RSD}=\frac{S D}{\bar{x}} \times 100 \%
$$

$\mathrm{SD}=$ standard deviation

$\bar{x}=$ average of measurable concentration

In addition, $\% \mathrm{RSD}_{\mathrm{R}}$ was obtained from $2 / 3$ CV Horwitz.

$$
\frac{2}{3} \mathrm{CV} \text { Horwitz }=\frac{2}{3} 2^{1-0.5 \log C} \times 100 \%
$$

where,

$\mathrm{C}=$ average of measurable concentration divided by $10^{6}$

\section{Significance Test}

F-test and t test were used to analyze significance difference between the two metods.

\section{F-test}

Hypothesis :

$\mathrm{H}_{0}: \mathrm{s}^{2}$ Nessler method $=\mathrm{s}^{2}$ Berthelot method

$\mathrm{H}_{1}: \mathrm{s}^{2}$ Nessler method $\neq \mathrm{s}^{2}$ Berthelot method

\section{t-test}

Hypothesis : 
$\mathrm{H}_{0}: \mu$ Nessler method $=\mu$ Berthelot method

$H_{1}: \mu$ Nessler method $\neq \mu$ Berthelot method where $s^{2}$ is variance, and $\mu$ is average or mean.

\section{DISCUSSION}

Ammonium levels in drinking water samples is very small so when measured by spectrophotometry less stable to perform the comparison of methods. Therefore, comparison of the methods was performed by addition standard. Comparison of this method was carried out on the parameters of linearity, precision, accuracy, F-test and ttest with these methods, Nessler method (SNI 01-3554-1998) and Berthelot one (SNI 01-3554-2006). Measurements of ammonium was carried out experiments on different methods using 2 different wavelengths, $420 \mathrm{~nm}$ at Nessler method, and $640 \mathrm{~nm}$ on Berthelot method. Selection is based on the wavelength of maximum absorbance complementary colors produced on analyte.

In Nessler reagent preparation, $\left(\mathrm{K}_{2} \mathrm{Hgl}_{4}\right)$ will react with $\mathrm{NH}_{4}{ }^{+}$ion in the examples of alkaline complex will produce yellow to brown the maximum absorbed at a wavelength of $400-480 \mathrm{~nm}$. The intensity of the color complex is the greater proportional to the amount of ammonium ion concentration contained in the sample. The equation is:

$\mathrm{NH}_{4}++2[\mathrm{Hgl} / 4]+4 \mathrm{OH} \rightarrow\left[\mathrm{HgO} \cdot \mathrm{Hg}\left(\mathrm{NH}_{2}\right) \mathrm{l}\right]+7 \mathrm{l}+3 \mathrm{H}_{2} \mathrm{O}$ (1)

Determination of ammonium using Nessler method is only used for the determination of ammonium in pure drinking water, natural water and purified waste water. It was because of the color of ammonium complex will be interfered by turbidity, color and substance deposition on the sample. Yellow color of the low concentration ammonium complexed with Nessler reagent can be measured with acceptable sensitivity in the wavelength range $400-425 \mathrm{~nm}$.

In Berthelot method, reaction produced blue color caused by indophenols formation (Figure 1). Ammonium in alkaline conditions reacted with hypochlorite thus becoming mono-chloramine compound (eq. 2). Presence of phenolic compounds and excess of hypochlorite caused the reaction producing indophenol compound (eq. 3 and eq. 4). Most commercial ammonia test kit used salicylate salt and others used different phenol and phenolic compounds (Loan et al., 2013) (Park et al., 2009) (Hasri and Mudasir, 2002).

The formation of indophenol needed long time, so it was added using nitroprusside to accelerate the reaction. Absorbance of indophenol blue compound was then measured at a wavelength of 640 $\mathrm{nm}$. The color was stable for up to 6 hours. The color formed can be interfered by calcium, and magnesium. Precipitation by EDTA can overcome it. Alkalinity as $\mathrm{CaCO}_{3}$ exceeds $500 \mathrm{mg} / \mathrm{L}$ and acidity to $100 \mathrm{mg}$ as $\mathrm{CaCO}_{3} / \mathrm{L}$ also can interfere the measurement. Indophenol complex measurements with a wavelength of 630$660 \mathrm{~nm}$ can be determined with ammonia concentration ranging from 0.02 to $2.0 \mathrm{mg} / \mathrm{L}$.

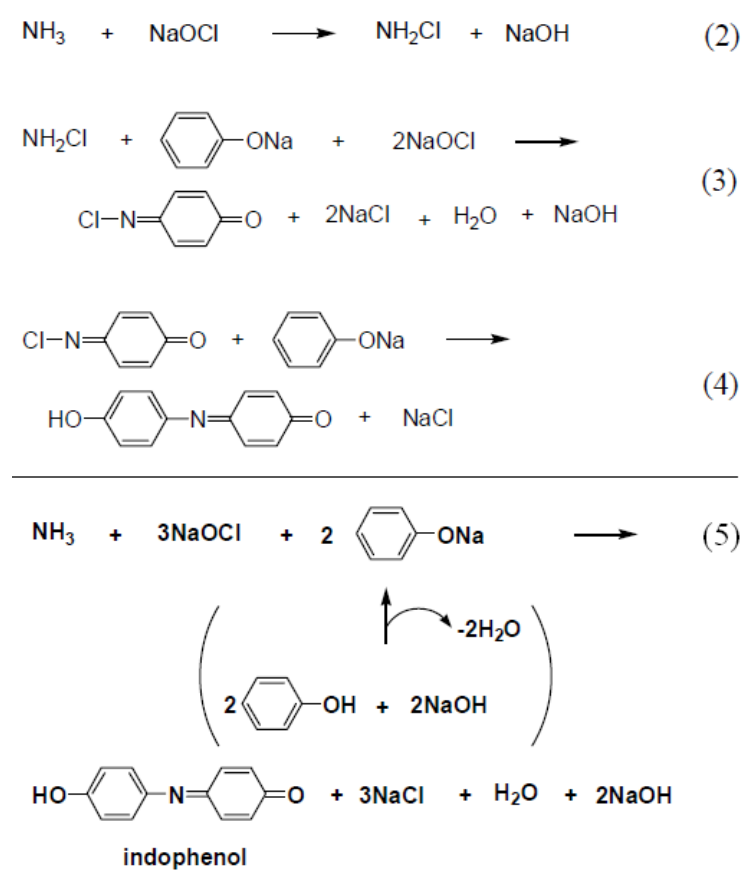

Figure 1. Indophenol formation

(Park et al., 2009)

Nitroprusside is necessary to form the indophenol blue derivative using salicylate. It has been also reported another modified Berthelot reaction using 1-naphthol without nitroprusside (Shoji and Nakamura, 2009). Precipitation of magnesium as hydroxide in an alkaline environment is another difficult 
point (Jeonget al., 2013). If a water sample contains other color or turbidity-causing substances (e.g., alkali ions such as $\mathrm{Ca}^{2+}$, $\mathrm{Fe}^{2+}, \mathrm{Mg}^{2+}$, and $\mathrm{HS}^{-}$), the Nesslerization cannot be applied directly. The alkali ions and sulfide can form turbidity-causing substances or floc when the water sample is treated with the Nessler reagent (Park et al., 2009). Due to Nessler method use mercury as color creation reagent, it was rarely applied. The Berthelot's method is more safely in use and highly sensitive, there for this method attracted an interest of scientists to develop it in research and application.

The test set was used for ammonia determination by the photometric method and visual method with ammonia concentration range from 0.00 to $1.00 \mathrm{ppm}$ as well as for ammonia in real water samples. The test methods compared with conventional spectrophotometric method showed that the results were agreed on each to other. Particularly, quick test by visual method (test-kit) met detection limit of $0.05 \mathrm{ppm}$ and relative error less than $25 \%$ is acceptable (Loan et al., 2013).

Table 1. Statistic Comparison between Nessler and Berthelot Methods

\begin{tabular}{lcc}
\hline Comparation & $\begin{array}{c}\text { Nessler method } \\
\text { SNI 01-3554-1998 }\end{array}$ & $\begin{array}{c}\text { Berthelot method } \\
\text { SNI 01-3554-2006 }\end{array}$ \\
\hline Linearity $(r)$ & 0.9995 & 0.9995 \\
\hline $\begin{array}{l}\text { Precision } \\
\text { (\% RSD) }\end{array}$ & 3.41 & 3.64 \\
\hline $\begin{array}{l}\text { Accuracy } \\
\text { (\% Recovery) }\end{array}$ & 101.05 & 105.63 \\
\hline Mean & 0.4131 & 0.3951 \\
\hline Variance, $\mathrm{s}^{2}$ & $1.99 \times 10^{-4}$ & $2.07 \times 10^{-4}$ \\
\hline
\end{tabular}

\section{Linearity}

Methods are described as linear when there is a directly proportional relationship between the method response and concentration of the analyte in the matrix over the range of analyte concentrations of interest (working range). Experiments for determination of ammonium in drinking water performed using 8 variations of standard concentrations as a comparison : 0.00 ; 0.20 ; $0.40 ; 0.60 ; 0.80 ; 1.40 ; 1.80$ and;
$2.00 \mathrm{ppm}$ (as nitrogen) and then converted into $\mathrm{NH}_{4}^{+}$.

The results of the linearity test for Nessler method was linear equation, $y=$ $0.1445 x+0.0597$ with a correlation coefficient ( $r$ ) of 0.9994. Whereas for Berthelot method the equation was $y=$ $0.702 x+0.0435$ with a correlation coefficient ( $r$ ) of 0.9995. Intercept of Berthelot method was higher than Nessler method. It showed that Berthelot method was more sensitive and had lower limit of detection. Based on the results of both, the methods still have a linear relationship between the concentration of the analyte in the sample to the instrument response (absorbance). Center for Supervision and Quality Control (BPMB) set the value of the correlation coefficient can be received was $\geq$ 0.995.

The results showed that both methods as a whole provide a proportionate response. Concentration of standards were also in the linier region. The slope of the curve is steeper with Berthelot method. It states that Berthelot method is more sensitive than the methods Nessler, Berthelot method generate a greater response than the Nessler method with the same concentration. So that Berthelot method can be used to analyze lower concentration on ammonium.

A good accuracy and precision can only be obtained when a good calibration procedure is adopted. Based on the BeersLambert Law, absorbance is the ratio of logarithm of intensity of incident light and intensity of transmitted light, or $A=\varepsilon C$ I. The absorbance $(A)$ is proportional to the concentration $(C)$ of the absorbing species, if absorptivity $(\varepsilon)$ and thickness of the medium (I) are constant.

\section{Precision}

A good test method when done should be able to generate good data precision. So this experiment is also a test of precision in both methods. Precision test showed the closeness between the test results with other test results on a test. The precision test is done by measuring the sample inspike $0.3863 \mathrm{mg} / \mathrm{L}$ ammonium with 7 replications preparation. 
The precision test conducted into the kind of repeatability, as done by analysts, instruments, equipment, and the same laboratory. Repeatabilityconcerns the test results obtained with the same method, on the same sample in the same laboratory, with the same equipment, by the same operator, in short intervals of time. To determine the repeatability the concentration of metals in the certificate materials described earlier was determined (Voicaet al., 2012). Repeatability can be aware of any random errors derived from sample preparation, such as pipetting, dilution standards, as well as the condition of the tools used.

Based on test, results obtained precision values for Nessler method were deviation standard (SD) of $0.0141 \mathrm{mg} \mathrm{L}^{-1}$ and the value of relative standard deviation (RSD) at $3.41 \%$, whereas the yield value Berthelot method were (SD) of $0.0144 \mathrm{mg} \mathrm{L}^{-}$ ${ }^{1}$ and (RSD) of $3.64 \%$ (Table 2). Precision is affected by the concentration of the analyte. Evident from the research found that the relative standard deviation increases with decreasing levels of analyte, so the precision test not only his views RSD, but needs to be compared with reproducibility standard deviation $\left(R S D_{R}\right)$. Based on these results both produce good accuracy, because both methods RSD is smaller than $2 / 3 \% \mathrm{RSD}_{\mathrm{R}}(2 / 3 \mathrm{CV}$ Horwitz). The precision value can provide information that this method can be used as a fixed method in the laboratory.

Table 2. Comparison of ammonium ion determination

\begin{tabular}{llc}
\hline \multirow{2}{*}{ Samples } & \multicolumn{2}{c}{ Conc. of $\mathrm{NH}_{4}{ }^{+}(\mathrm{mg} / \mathrm{L})$} \\
\cline { 2 - 3 } & $\begin{array}{c}\text { Nessler } \\
\text { method }\end{array}$ & $\begin{array}{c}\text { Berthelot } \\
\text { method }\end{array}$ \\
\hline Sample 1 & 0.0235 & -0.0106 \\
\hline Sample 2 & 0.0221 & -0.0152 \\
\hline Spiked sample 1 & 0.4035 & 0.3744 \\
\hline Spiked sample 2 & 0.3979 & 0.4091 \\
\hline Spiked sample 3 & 0.4118 & 0.3743 \\
\hline Spiked sample 4 & 0.4028 & 0.4007 \\
\hline
\end{tabular}

\begin{tabular}{lcc}
\hline Spiked sample 5 & 0.4284 & 0.4028 \\
\hline Spiked sample 6 & 0.4118 & 0.4024 \\
\hline Spiked sample 7 & 0.4360 & 0.4022 \\
\hline Sample (average) & 0.0228 & -0.0129 \\
\hline Spiked sample (Mean) & 0.4131 & 0.3951 \\
\hline SD & 0.0141 & 0.0144 \\
\hline$\% \mathrm{RSD}^{\text {\% RSD }}$ & 3.41 & 3.64 \\
\hline
\end{tabular}

Precision is affected by random error, among others instrument instability, temperature variation, reagents, technological diversity and different operators. A random error is an error in measurement because of interference and different conditions of each measurement to produce different numbers. This random error factor can actually be reduced by doing a lot of repeat measurements.

Both methods are good precision, but the Nessler method better precision as RSD is smaller than the result of the Berthelot method. Preparation Nessler method was complicated because using 3 reagents. These experiments explain the more complicated construction method, the result is increasingly less good repeatability caused by random errors and systematic errors increases. Repeatability gives an idea of the sort of variability to be expected when a method is performed by a single analyst on one piece of equipment over a short timescale, i.e. the sort of variability to be expected between results when a sample is analysed in duplicate.

\section{Accuracy}

Accuracy test refers to the notion precision of the results. The test was done by measuring the sample and sample that was spiked with $0.3863 \mathrm{ppm}$ of ammonium in 7 repetitions measurement then the average was counted. The average value of a series of measurement results more convincing than one measurement. The more the number of repetitions of measurement, the results of the mean data will be more reliable. Accuracy was 
determined by comparing the measured concentration with the certified values and was expressed as percentage recovery $R$ [\%] (Voicaet al., 2012). The value of the sample concentration that the analyte adds should not exceed the highest working range limits on the scope of the test method used. The concentration of samples that the analyte added has to be included in the linear regression of the calibration curve used. The analytical (standard) requirement to the sample must have the properties of standard solution added to a high purity spike, having a matrix almost equal to the sample; and have solubility almost the same as the sample.

The recovery value of close to $100 \%$ indicates that the method has good accuracy in demonstrating the suitability of the mean level of a measurement that is proportional to the true value (true value). Recovery (accuracy) obtained from the testing of compounds known concentration levels and compared to the amount of analyte obtained. The recovery of an analyte in an assay is the detector response obtained from an amount of the analyte added to and extracted from the matrix, compared to the detector response for the true concentration of the pure authentic standard (seized materials).

Table 3. Comparison of recovery (\%) between two methods

\begin{tabular}{ccc}
\hline Samples & $\begin{array}{c}\text { Nessler } \\
\text { method }\end{array}$ & $\begin{array}{c}\text { Berthelot } \\
\text { method }\end{array}$ \\
\hline 1 & 98.54 & 100.28 \\
\hline 2 & 97.11 & 109.24 \\
\hline 3 & 100.69 & 100.24 \\
\hline 4 & 98.36 & 107.07 \\
\hline 5 & 104.99 & 107.62 \\
\hline 6 & 100.69 & 107.51 \\
\hline 7 & 106.96 & 107.47 \\
\hline Mean & 101.05 & 105.63 \\
\hline
\end{tabular}

The mean \% recovery on Nessler method was $101.05 \%$ while on Berthelot method was $105.63 \%$. The results showed that both methods are chosen to have a range of percent recovery (\% recovery) which express the degree of accuracy qualified acceptance. Terms of acceptance accuracy is $95 \%$ - $110 \%$ percent return of the acquisition. Recovery experiments should be performed by comparing the analytical results for extracted samples at three concentrations (typically those corresponding to control samples used to evaluate a method's precision and accuracy). Recovery of the analyte need not to be $100 \%$, but the extent of recovery (of the analyte and the internal standard) should be consistent (for all concentrations tested), precise and reproducible (better than 20\%) (United Nations Office on Drugs and Crime, 2009).

The major difficulty in evaluating accuracy is the fact that the actual content of the analyte to be tested is unknown. Accuracy is expressed as a percent recovery recovery (analytical) added. The percentage recovery test is performed by analyzing the enriched examples with the specified number of analyte. The absolute amount obtained from this analysis and the amount obtained from the same test for the sample (without the addition of the analyte) can be used to determine the value of the recovery of the analyte. Accuracy criteria depend on the concentration of the analyte in the sample matrix and the method of equation (RSD).

Determination of accuracy of a method usually there are errors that cause the value of accuracy obtained small or not exactly $100 \%$, this error is caused by personal errors such as pemipetan and systematic errors such as equipment or reagents used. However, systematic errors in principle can be identified and minimized.

\section{Significance Test}

Significance test is an approach to test whether the difference between the two results is significant, or whether it can be accounted for merely by random variations (Miller and Miller, 2010). The $t$-test is done by comparing the results of the Nessler and Berthelot to determine whether the difference between two methods is significance or not. Both of these methods 
can be said not differ significantly if the results $t_{\exp }$ smaller or equal to $t_{\text {crit. }}$ In general, the confidence interval used was $95 \%$, since when do the work in the laboratory is likely there is a random or systematic errors that can cause a measurement error of the estimated error is $\pm 5 \%$. So it is generally $95 \%$ confidence interval is used when the work is done on a laboratory scale.

F-test was conducted to compare standard deviations of both methods. From the $F$-test can find random errors. Table 1 and Table 4 show that the value of the variance $\left(s^{2}\right)$ of both method for determining ammonium in drinking water were not significantly different. The resulting variance $\left(\mathrm{s}^{2}\right)$ is $1.99 \times 10^{-4}$ and $2.07 \times 10^{-4}$ (each obtained from 7 measurements on samples in-spike), the value of $F$ obtained $\left(F_{\text {exp }}\right)$ is 1.043. Magnitude $F$ table $\left(F_{\text {crit }}\right)$ at 6 degrees of freedom at the $95 \%$ confidence interval is 4,284 .

$F_{\exp }(1.043)$ is smaller than the value $F_{\text {crit }}(4.284)$, then there is no meaningful difference between the two variances at $95 \%$ confidence interval. The two methods were not significantly different. These results are due to $t_{\text {crit }}$ value (2.45) is greater than $t_{\text {exp }}$ (2.36), so the Berthelot method can replace the previous one, Nessler method.

Table 4. Significant Difference Test between two methods

\begin{tabular}{ccc}
\hline Samples & $\begin{array}{c}\text { Nessler } \\
\text { method }\end{array}$ & $\begin{array}{c}\text { Berthelot } \\
\text { method }\end{array}$ \\
\hline 1 & 0.4035 & 0.3744 \\
\hline 2 & 0.3979 & 0.4091 \\
\hline 3 & 0.4118 & 0.3743 \\
\hline 4 & 0.4028 & 0.4007 \\
\hline 5 & 0.4284 & 0.4028 \\
\hline 6 & 0.4118 & 0.4024 \\
\hline 7 & 0.4360 & 0.4022 \\
\hline Mean & 0,4131 & 0.3951 \\
\hline$s^{2}$ & $1.99 \times 10-4$ & $2.07 \times 10-4$ \\
\hline$F_{\text {exp }}$ & \multicolumn{2}{c}{1.043} \\
\hline
\end{tabular}

\begin{tabular}{lll}
\hline \multicolumn{2}{c}{$F_{\text {crit }}$} & 4.284 \\
\hline$t_{\exp }$ & 2.36 & \\
\hline$t_{\text {crit }}$ & 2.45 & \\
\hline
\end{tabular}

\section{CONCLUSIONS}

Based on experiments that have been done can be seen that the Berthelot method (SNI 01-3553-2006) generated a greater response than Nessler method (SNI 013553-1998). Nessler methods and Berthelot method both have good linearity. Test precision and accuracy test produced both precision and accuracy are both having already qualified acceptance. The results show that the real difference test both methods did not differ significantly by $95 \%$ confidence interval. The Nessler method was simple, but the Berthelot method was more sensitive. Whereas based on statistical analysis, there was no significant difference between two methods, so that both were still valid and interchangeable for analysis in laboratory.

\section{ACKNOWLEDGEMENT}

Thanks to Laboratory of Food and Beverage, Center for Supervision and Quality Control (BPMB) Ciracas, Jakarta for providing chemicals and instruments for analysis.

\section{REFERENCES}

Hasri and Mudasir, Study of The Effect of Ethanol Addition and Solution Heating On The Determination of Ammonia in Water by Indophenol Blue Method, Indonesian J. Chemistry, 2002, vol.2, no. 2, 97-101.

Jeong, H., Park, J., and Kim, H., Determination of $\mathrm{NH}_{4}{ }^{+}$in Environmental Water with Interfering Substances Using the Modified Nessler Method, J. of Chemistry, vol. 2013, article ID 359217. 
Loan, D.K., Con, T.H., Hong, T.T. and Mai Ly, L.T., Quick Determination of Ammonia lons in Water Environment Based on Thymol Color Creating Reaction, Environ. Sciences, 2013, vol. 1, no. 2, pp. 83 - 92.

Miller, J.N. and Miller, J. C., 2010, Statistics and Chemometrics for Analytical Chemistry; Sixth edition, Essex : Pearson Education Ltd., England.

Park, G.E, Oh, H.N., and Ahn, S., Improvement of the Ammonia Analysis by the Phenate Method in Water and Wastewater, Bull. Korean Chem. Soc., 2009, vol. 30, no. 9, pp. 2032-2038.

Shoji, T. and Nakamura, E., Flow Injection Analysis with Spectrophotometry for Ammonium ion with 1-Naphthol and Dichloroisocyanurate, J. Flow Injection Anal., 2009, vol. 26, no. 1, pp. 37-41.

Tanzer Dieter. Means and method for the determination of ammonia ions, US Patent 5620900. Issued on April 15th 1992.

Tzollas, N.M., Zachariadis, G.A., Anthemidis, A.N. and Stratis, J.A., A New Approach to Indophenol Blue Method for Determination of Ammonium in Geothermal Waters with High Mineral Content, Intern. J. Environ. Anal. Chem., 2010, vol. 90, no. 2, pp. 115-126.

United Nations Office on Drugs and Crime, 2009, Guidance for the Validation of Analytical Methodology and Calibration of Equipment used for Testing of Illicit Drugs in Seized Materials and Biological Specimens, New York : United Nations.

Voica, C., Dehelean, A., lordache, A., Geana, I., Method Validation for Determination of Metals in Soils by ICP-MS, Romanian Reports in Physics, 2012, vol. 64, no. 1, pp. 221231 